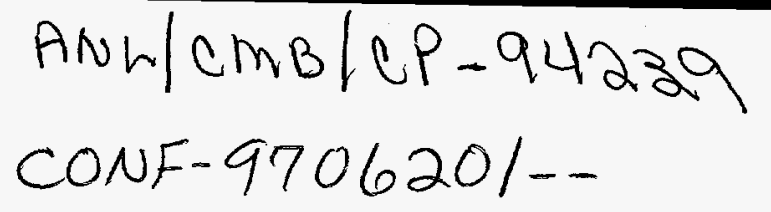

\title{
CHANGES IN GENE EXPRESSION FOLLOWING EMF EXPOSURE
}

\section{RECEIVED OCT 241997 OSTI}

\author{
Gayle E. Woloschak, ${ }^{1}$ Tatjana Paunesku, ${ }^{1}$ Chin-Mei Chang-Liu, ${ }^{1}$ \\ Lise Loberg, ${ }^{2}$ James Gauger, ${ }^{2}$ and David McCormick ${ }^{2}$ \\ ${ }^{1}$ Center for Mechanistic Biology and Biotechnology \\ 9700 South Cass Avenue \\ Argonne National Laboratory \\ Argonne, IL 60439-4833 \\ ${ }^{2}$ IIT Research Institute \\ 10 West 35th Street \\ Chicago, IL 60616-3793

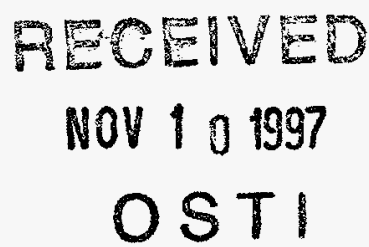

\section{INTRODUCTION}

Experiments were designed to examine the effects of electromagnetic field (EMF) exposure on specific gene expression, an effect that can be deleterious, beneficial, or neutral, depending on the long-term consequences; however, the proof of a reproducible, quantitative biological effect (such as change in gene expression) will lead to later experiments aimed at determining the relative contribution of these changes to cellular consequences. Past work by ourselves ${ }^{1-4}$ and by others ${ }^{5-7}$ has shown that measures of gene expression are extremely sensitive indicators of the cellular and biological effects of ionizing radiation, with transcriptional changes being detected by exposure of cells to doses of $\gamma$-rays as low as $0.01 \mathrm{cGy}$ that have no pronounced cellular consequences. On the basis of this work, we hypothesized that measures of gene expression will be equally sensitive to EMF effects on cells.

\section{METHODS}

\section{Cell Lines and Exposure Systems}

HeLa cells used routinely by our group ${ }^{8}$ were used in these experiments. The in vitro EMF laboratory at IIT Research Institute (IITRI) is equipped with an in vitro magnetic field linear exposure system, model 1 (Electric Research and Management, Inc. [ERM]; State College, PA). The exposure system consists of two identical and interchangeable exposure modules, a central environmental control incubator, a cell stock chamber, and computerized field control and monitoring equipment. Each exposure module incorporates a pair of nested Merritt coil sets that surround an insulated acrylic exposure chamber (sham or exposure). The inner Merritt coil set provides the primary field exposure, and the outer coil set limits stray fields. The system is capable of generating $60-\mathrm{Hz}$ magnetic flux densities ranging from $10 \mathrm{mG}$ to $10 \mathrm{G}$, with field uniformity of $5 \%$ or better throughout the $40 \times 103 \mathrm{~cm}^{3}$ exposure volume. Because the field coils feature bifilar windings, an "energized" sham module is possible. The combined cross-talk and self-generated fields in the sham exposure volume are less than $1 \mathrm{mG}$ (neglecting background ambients) for a field of $10 \mathrm{G}$ in the treatment exposure volume.

A standard commercial incubator, positioned between the exposure modules, provides environmental control for both exposure chambers as well as the cell stock chamber; because of magnetic fields generated by components of the incubator, the incubator itself is not used for cell maintenance. The incubator has been modified with external blower packs, and treated air is fed to and returned from the remote cell stock and exposure chambers via insulated polyvinyl chloride pipe. 


\section{DISCLAIMER}

This report was prepared as an account of work sponsored by an agency of the United States Government. Neither the United States Government nor any agency thereof, nor any of their employees, makes any warranty, express or implied, or assumes any legal liability or responsibility for the accuracy, completeness, or usefulness of any information, apparatus, product, or process disciosed, or represents that its use would not infringe privately owned rights. Reference herein to any specific commercial product, process, or service by trade name, trademark, manufacturer, or otherwise does not necessarily constitute or imply its endorsement, recommendation, or favoring by the United States Government or any agency thereof. The views and opinions of authors expressed herein do not necessarily state or reflect those of the United States Government or any agency thereof. 


\section{DISCLAMISR}

Portions of this docounent may be illegible in electranic image products. Inoges are produced frose the best avainable original docemeot 
Differential display (dd) of eukaryotic mRNA by means of the polymerase chain reaction (PCR) is a technique developed by Liang and Pardee ${ }^{9}$ to separate and, eventually, to clone individual messenger RNAs differentially expressed in mRNA preparations from similar cells. The method was carried out essentially as described. ${ }^{4}$ Bands were extracted from the dried sequencing gel for reamplification. Before the sequencing gel was exposed to $x$-ray film, bands of interest were excised, re-amplified, and sequenced essentially as described. ${ }^{4}$ For all genes, we verified induction following EMF exposure by Northern blots. RNA was purified in our laboratory by isolation in guanidine isothiocyanate, extraction from phenol, and precipitation from $3 \mathrm{M}$ sodium acetate, $\mathrm{pH}$ 6.0. ${ }^{1-3}$ Poly(A)+ RNA was isolated by oligo-dT cellulose column chromatography.

Northern blot analysis allowed for the identification of EMF-inducible RNA sequences by comparison with RNA extracted from untreated cells; RNA was separated by using formaldehyde agarose gel electrophoresis as described previously.$^{1-3}$ Northern transfers and hybridization were performed as described by Woloschak et al..$^{1-3}$

\section{RESULTS}

Differential-display experiments were designed to identify genes induced by EMF exposures in HeLa cells. Figure 1 depicts one such differential-display gel in which different primers were used to amplify cDNAs derived from two different sets of control cells grown in the laboratory at Argonne National Laboratory (lanes 1 and 2) and from sham-exposed and exposed ( $1 \mathrm{G}, 24 \mathrm{~h}$ ) cultures grown at IITRI (lanes 3 and 4). Studies at ITTRI were conducted under fully blinded conditions. On the basis of the many differences in lane 3 relative to the other lanes, we predicted that lane 3 had been exposed to EMF (when Jim Gauger broke the code, indeed lane 3 was from the EMF-exposed cells). A single difference alone would not have allowed for the prediction, but the multiple differences allowed us to conclude that EMF exposure does affect gene expression. Note that the -RT lane (without reverse transcriptase) was negative in all experiments, demonstrating an absence of contaminating DNA in the reactions.

The six bands (five affected by EMF and one control band) in Figure 1 were all cut out of the differential display gel and sequenced as examples of induced or repressed genes. The bottom band in the last primers set was chosen to be a loading control. These bands were then used to examine more detailed expression by Northern blots. These experiments were controlled for equal loading by using the loading control band as well as $\beta$-actin and rRNA controls. With no knowledge of the code, we predicted (on the basis of differential-display patterns in Figure 1) that lane 3 should be the EMF-exposed lane, and lane 4 should be the sham-exposed one; this prediction was later shown to be true. Two bands called R1 and 13 were confirmed as being induced following EMF exposure.

We performed sequence analysis of the bands we obtained from Figure 1. Once sequenced, a search through GenBank, dbEST, and other sequence databases was performed to identify the genes. The search of I2, I3, and R1 sequences through GenBank and dbEST revealed identities to no known gene, but identities to several EST sequences were noted. Band R2 is a mixture of two different $3^{\circ}$-UTRs (untranscribed region); the sequence resulting from this band was difficult to read.

Interestingly, the most highly induced band (I3) has a potential regulatory region in the 3'-UTR. A similar sequence was reported by our group in a UV-induced gene (Woloschak and Paunesku, in press) and has subsequently been shown to bind to sequence-specific proteins (Paunesku and Woloschak, in preparation). A similar sequence in an EMF-induced gene is, therefore, of great interest. These recent results in our laboratory suggest the presence of a conserved sequence motif in EMF-regulated genes. Proteins bind to this element in response to EMF exposure.

\section{DISCUSSION}

Covering $10 \%$ of the genome, we have identified only two EMF-induced genes in HeLa cells. On the basis of these preliminary data, we estimated that the number of genes meeting these criteria will be small - no more than 20. This estimate was determined by using analysis of dd-RT-PCR primers needed to cover the expression of $95 \%$ of the genes in the genome. Bauer et al. ${ }^{10}$ have estimated that if 6 -mers are used for dd-RT-PCR, $95 \%$ of the genome will be "covered" if 20 primer sets (specially selected) are used in combination with the four different dT primers. We have identified five genes as candidates, only two of which are induced.

The identification of possible regulatory elements for this response (see preliminary data) is exciting as a possible mechanism for EMF induction. These elements could play a role in transcriptional activation, mRNA stability, or intracellular transport. Nevertheless, these findings are relatively recent in our laboratory. Additional confirmation and repetition are required before the role of these elements in EMF-mediated gene modulation can be fully delineated. 
Figure 1. Differential display using primers listed across the top. In all cases, $T_{n} V C$ was labeled; primer sequences are defined in the research methods section. - RT lane is without reverse transcriptase. Samples in lanes 1 and 2 are derived from control unexposed cells grown in two different incubators at Argonne National Laboratory. Lanes 3 and 4 are derived from sham- or EMF-exposed cells (done blindly) at IITRI. We later confimed that lane 3 was from EMF-exposed cells. Boxed bands were selected for further study (five affected by EMF and isolated from EMF-exposed cells and one control band). 


\section{ACKNOWLEDGMENT}

This work supported by the U.S. Department of Energy, Office of Health and Environmental Research, under Contract No. W-31-109-ENG-38. This publication was also made possible by grant number R01 85E40 and R01 ES 07093 from the National Institute of Environmental Health Sciences (NIEHS), NIH. Its contents are solely the responsibility of the authors and do not necessarily represent the official views of the NIEHS, NIH.

\section{REFERENCES}

1. G.E. Woloschak, C.-M. Liu, and P. Shearin-Jones, Regulation of protein kinase $\mathrm{C}$ by ionizing radiation. Cancer Res. 50:3963 (1990).

2. G.E. Woloschak, C.-M. Liu, P.S. Jones, and C.A. Jones, Modulation of gene expression in Syrian hamster embryo cells following ionizing radiation, Cancer Res. 50:339 (1990).

3. G.E. Woloschak, P. Shearin-Jones, and C.-M. Chang-Liu, Effects of ionizing radiation on expression of genes encoding cytoskeletal elements: kinetics and dose effects, Mol. Carcinog. 3:374 (1990).

4. G.E. Woloschak, T. Paunesku, C.-M. Chang-Liu, and D.J. Grdina, Expression of thymidine kinase messenger RNA and a related transcript is modulated by radioprotector WR1065, Cancer Res. 55:4788 (1995).

5. A.J. Fornace, Jr., Mammalian genes induced by radiation: Activation of gene associated with growth control, Annu. Rev. Genet. 26:507 (1992).

6. P. Herrlich, H. Ponta, and H.J. Rahmsdorf, DNA damage-induced gene expression: Signal transduction and relation to growth factor signaling, Rev. Physiol. Biochem. Pharmacol. 119:187 (1992).

7. G.E. Woloschak, Radiation-induced responses in mammalian cells, in: Stress-Inducible Processes in Higher Eukaryotic Cells, T. Koval, ed., Plenum Publishing Corp., New York (1997).

8. G.E. Woloschak, and T. Paunesku, Mechanisms of radiation-induced gene responses, Stem Cells, in press (1997).

9. P. Liang, and A.B. Pardee, Differential display of eukaryotic messenger RNA by means of the polymerase chain reaction, Science 257:969 (1992).

10. D. Bauer, H. Miller, J. Reich, H. Reidel, V. Ahrenkiel, P. Warthoe, and M. Strauss, Identification of differentially expressed mRNA species by an improved display technique (DDRT-PCR), Nucl. Acids Res. 21:4272 (1993). 


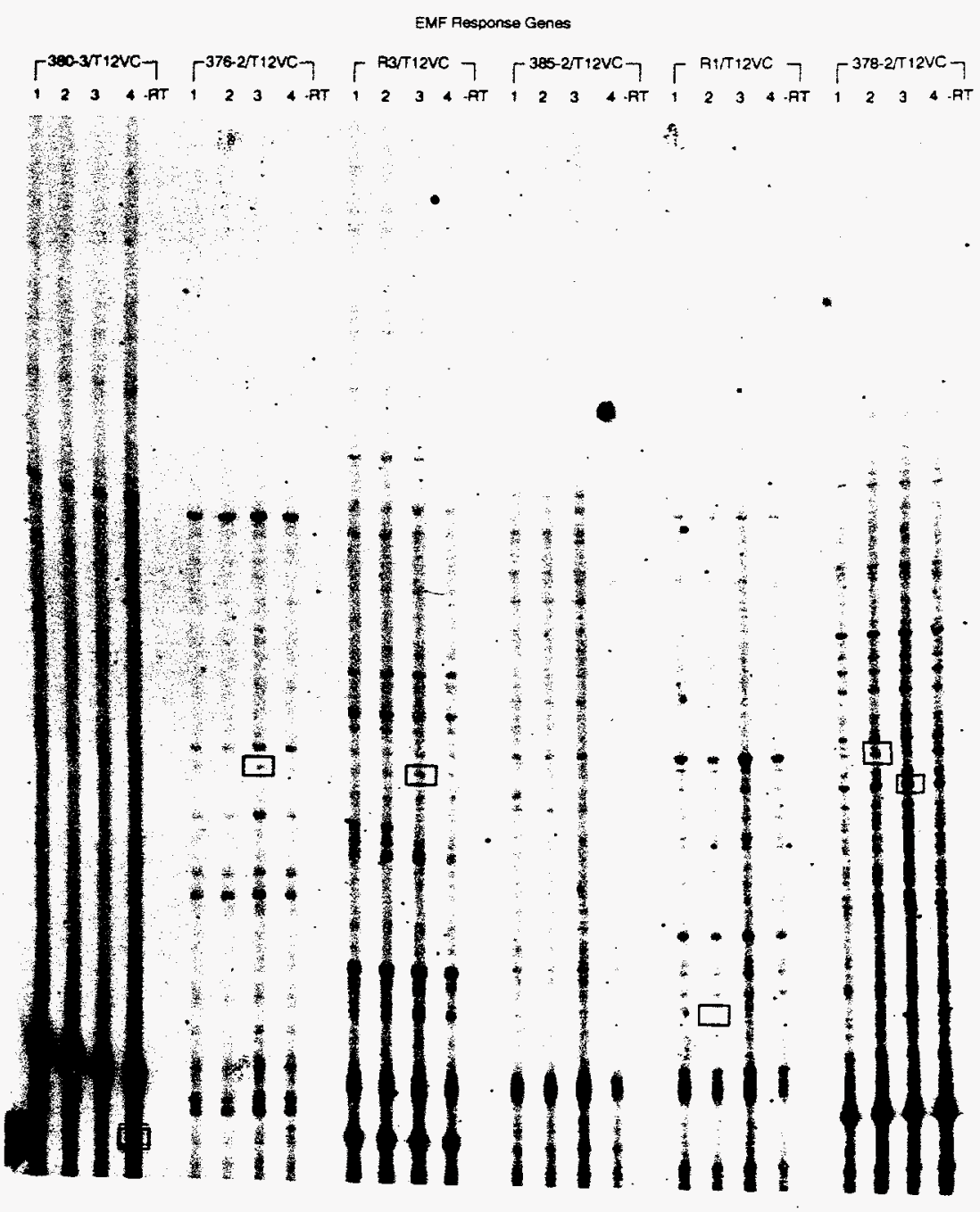

